\title{
The role of episodic plain formation and continuous etching and stripping processes in the End-Tertiary landform development of SE Kenya
}

by

A. Veldkamp, Wageningen and A.P.Oosterom, Tanga with 6 figures and 3 photos

Zusammenfassung. Im südöstlichen Kenia waren zurückweichende Hangflächen und zugehörige Flächenbildung episodische Prozesse, die mit Perioden hoher Erosionsbasen assoziiert sind. Sowohl Sedimentation als auch Erosion tragen an der Reliefnivellierung bei. Die Korrelation von binnenländlichen tektonischen Bewegungen mit Veränderungen in den regionalen Erosionsbasen zeigt, daß eine tektonische Beherrschung der spättertiären Reliefentwicklung mehr als wahrscheinlich ist. Im Gegensatz zum Pediplanekonzept, welches ein Absinken der Erosionsbasis als Auslösung annimmt, wird der hier vorgestellt planekonzept, welches ein Absinken der Erosionsbasis als Auslösung annimmt, wird der hier vorgestellte Nivellierungsprozeß durch einen Anstieg der Erosionsbasis initiierc. Dieser Prozess verläuft nicht kontinuierlich, sondern scheint beinahe zum Stillstand zu kommen, sobald die regionale Erosionsbasis abgesunken ist. Desweiteren erlaube dieses Konzept Witterungs- und Erosionsprozessen außerhalb des Einflußbereiches der Erosionsbasisänderung fortzufahren, wodurch das scheinbare Paradoxum zeitgleicher Flächenbildung und Lösungs- und Abtragungsprozesse gelöst wird.

Summary. Scarp retreat and related plain formation in the southeastern Kenyan landscape were episodic processes and associated with periods of high base-levels. Both sedimentation and erosion contributed to landscape leveling. Correlation of tectonic movements in the interior and regional base-level chas shows that a tectonic control over the Late Tertiary plain formation is more than likely. The propose leveling process opposes the pediplanation concept in being trigered off by based level lowering Moreover, it is not conrinuous, but seems to come to an anost stand sill as son baseregional base level is lowered. It further allows weathering and to outside the reach of base-level chanes and can forside the reach of base-level changes and can therefore solve the apparent paradox between plain

Résumé. Le retrait des versants raides et la formation de plaines dans le paysage du SE du Kenya ont été des processus episodiques et associés à des niveaux de base élevés. Ensemble, la sédimentation et l'érosion ont contribue au nivellement du paysage. La corrélation de mouvements tectoniques à l'intérieur, avec des changements de niveaux de base régionaux montre que l'influence de la tectonique pendant la formation de plaines au cours du Tertiaire récent est plus que probable. Le processus de nivellement proposé oppose deux conceptions de la pédiplanation; dans le cas présent, elle serait provoquée par un relèvement du niveau de base plutôt que par un abaissement de celui-ci. De plus, le processus n'est pas continu, mais semble en arriver à un état de quasi stabilité aussitôt que le niveau de base régional est abaissé. En oures permer la poursuite de l'action des processus d’altération er d'érosion dans des régions extérieures à zone d'influence des changements de niveau de base, et peurs de ce fait rásoudre le pandoxe appar a entre la formation de plaines et les processus synchrones de découpage et de décapage. 


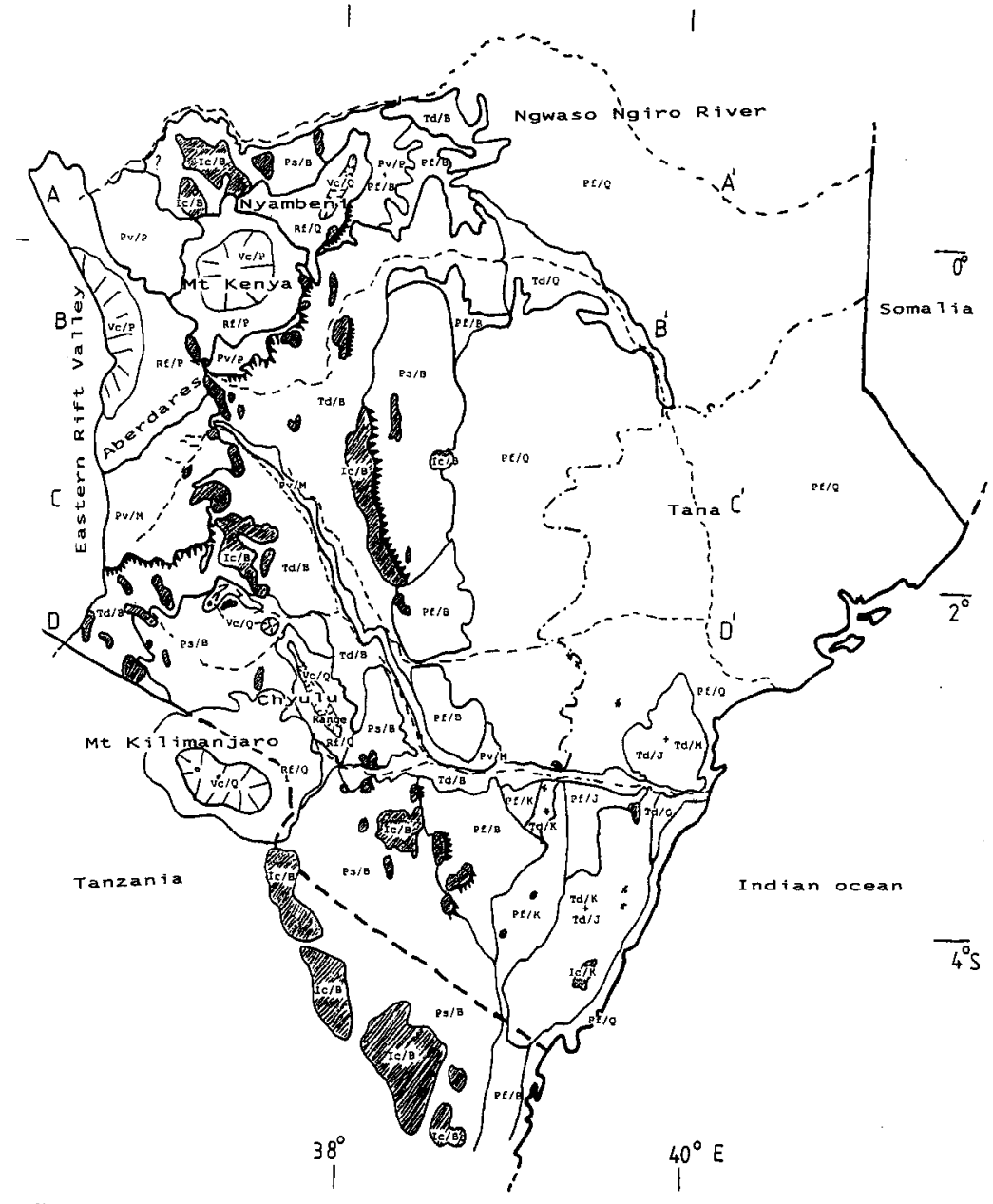

Fig. 1. Geomorphological map of SE Kenya, legend see opposite page.
Introduction

The relief of SE Kenya (fig. 1) is dominated by extensive flat plains with abruptly rising inselbergs. The plains are generally considered to represent the so-called EndTertiary erosion surface (SAGgerson \& BAKER 1965, OJANY \& OGENDO 1973 OJANY 1969,1978). The absence of lithological-control on these plains is striking and fits the concept of cyclic and global pediplanation (KING 1962, 1976). However, the presence of widespread sedimentary plains within the End-Tertiary surface (SOMBROEK et al. 1982) suggests that besides pediplanation processes sedimentation played a significant role in the relief development of SE Kenya. Moreover, deep regoliths and strongly weathered soils on many foot slopes of scarps, bounding the extensive plains indicate that pediplanation is not very active under present (semi-arid) conditions.

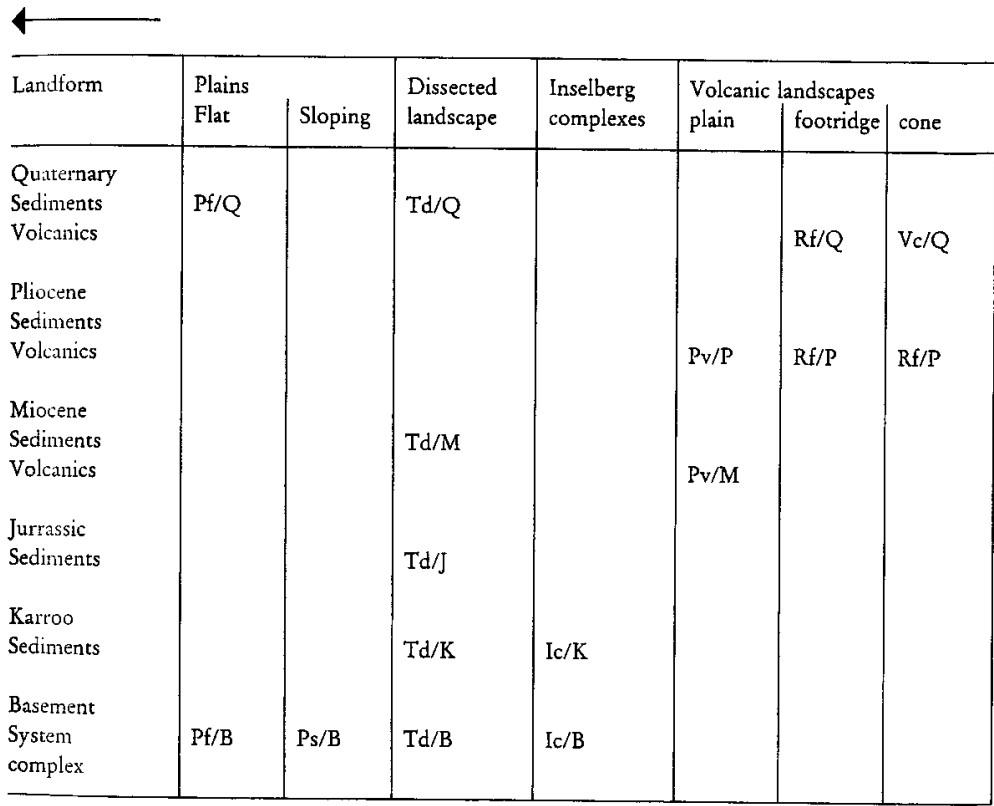

River

Boundary between Late/Middle Pleistocene and Early Pleistocene

* Small Inselberg complexes

A A' position of sections fig 2, 3, 4, 5 . 
In contrast to the levelled areas, a strong lithological dependence is characteristic for the inselberg complexes and other stripped areas above and below the level of the plains (Veld kamp \& Visser 1986, 1992, Goudie et al. 1984, Pye et al. 1984 1986). The development of the relief in these parts is more conveniently explained by the processes of etching and stripping than by pediplanation (THOMAs 1974, 1980, 1989). However, etching and stripping processes tend to increase relief instead of reducing it. Therefore, it is unlikely that they are the only processes contributing to the formation of extensive plains. Processes leading to the development of a lithologically controlled relief and to the formation of lithologically independent plains are opposed to each other. Yet they appear to have occurred contemporaneously during the Late-Tertiary relief development of SE Kenya.

This study aims to contribute to the solution of this contradiction. The spatial and chronological relationships between the two opposing relief-forming processes have been investigated. It will be demonstrated that the current concept of cyclic and global pediplanation needs considerable revision to explain the landform development in SE Kenya. The geological time scale of HARLAND et al. (1990) has been used for geochronological reference.

\section{Geological context}

The geology of SE Kenya is dominated by structures of the Precambrian basement of the Mozambique Belt System and the Paleo-Cenozoic sedimentary Mombasa-Lamu Basin (fig. 2.). Cenozoic volcanism and associated rifting also play an important role in the geological history of the area.

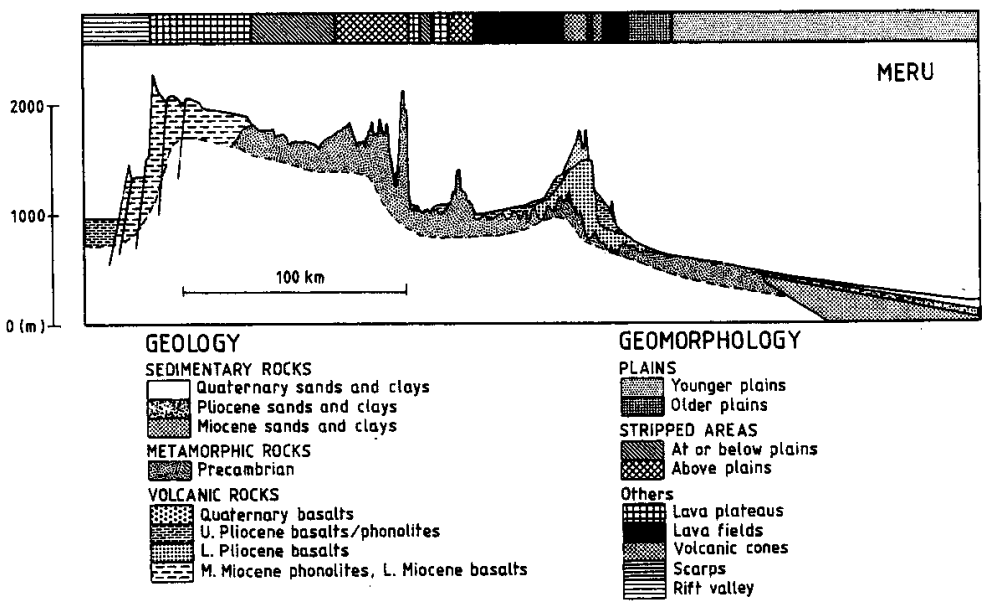

Fig. 2. Meru transect. (section $A-A^{\prime}$ in fig. 1 )

\section{Precambrian basement}

The Precambrian basement consists mainly of metamorphic rocks. They originate from psammitic, (semi-) pelitic and calcareous sediments with thin intercalations of basic volcanics from sills or lava flows. These materials were deposited in geosynclinal throughs on a Pre-Mozambiquian basement during the Middle Proterozoic (CHOUBERT \& FAURET-Muret 1976). Deformation of the deposits took place in three major orogenic episodes (Horkel et al. 1979, Pohl \& Nitedermayer 1979).

Periods of uplift and denudation followed this deformation and have resulted in the characteristic scenery of SE Kenya with flat sky-lines broken by abruptly rising inselbergs. The nature of the basement rocks and their structural control are reflected by the position of the inselbergs (fig. 1.). Minor topographical variations connected with the nature of the subsurface are revealed in the dissected (stripped) basement areas (Veldxamp \& Visser 1992, Pye et al. 1986).

\section{Mombasa-Luma Basin}

The sedimentary basin in the eastern part of the study area originates from a Paleozoic/Mesozoic triradial rift system in East Africa (CANNON et al. 1981). The oldest sedimentary rocks of the Mombasa-Lamu basin are exposed in the southwestern limit of the study area. They are part of the Karroo System and consist mainly of Permian to Lower Jurassic sandstones. The rocks have been deposited in fluvial, lacustrine and deltaic environments. From Middle Jurassic to Lower Cretaceous marine conditions prevailed and limestone and shales were deposited. Deformation of the sediments by several events of faulting led to tilting and very gentle folding. From the Late Cretaceous onwards true oceanic conditions prevailed along the coast of Kenya (CANNon et al. 1981). The center of deposition shifted towards the middle of the Lamu embayment. Its almost continuous succession of Mesozoic and of the Lamu embayment. Its almost continuous succession of Mesozoic and Linton 1973, Karanja 1983). During the Pliocene and Pleistocene alternating fluvial and lagoonal superficial sediments were deposited (SAGGERSON \& BAKER 1965 OOSTEROM 1988, 1989).

The relief of the Mombasa-Lamu Basin consists mainly of flat sedimentary and erosional plains with scattered inselbergs. Topographic breaks between the erosional plains of different lithology are absent in non-dissected areas (e. g. Tsavo-East National Park). Typical cuesta landscapes have developed in more dissected areas (OosTEROM 1988). The relief of the coastal part of the study area consists of marine terraces and plateaus with an abraded subsurface. When dissected, the morphology is again strongly controlled by the nature and structure of the underlying rocks.

\section{Cenozoic volcanism}

The oldest Cenozoic volcanic rocks in the study area (fig. 1) are the Yatta phonolites. The flowed in a Miocene valley system dated at $13.2 \mathrm{my}$ BP (EvERDEN \& CURTIS 1965). Relief inversion has resulted in the present Yatta plateau (photo 1). Phonolitic flood lavas of comparable age underlie the Kapiti plains. Flood lavas of Late Miocene age are known as the Rumuruti and Thompson's Falls phonolites (MC CALL 1967, 
the shoulder of the Kenyan Rift Valley. Coastal plateaus and terraces not shown on the cross sections form the transition to the Indian Ocean.

\section{Younger plains}

The younger plains have an overall gradient of about $0.2 \%$ and occur parallel to the coast in the eastern part of the study area. They consist of sedimentary and erosional parts grading into each other without clear topographic breaks. The plains are active-

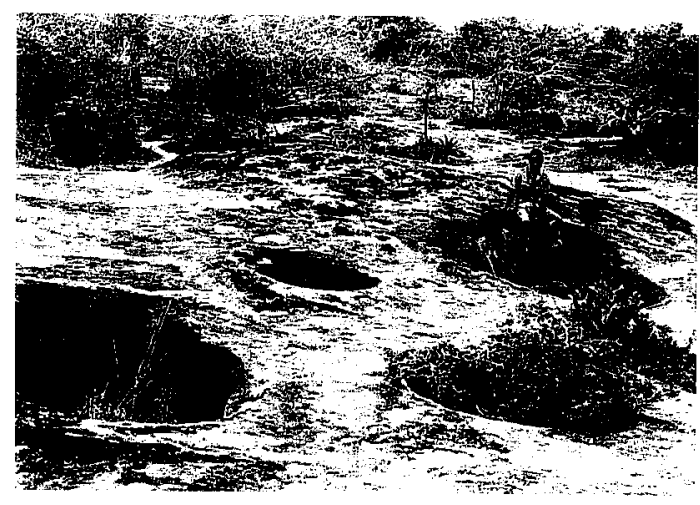

Photo 2. Potholes in transition zone from younger to older plains. 1967, BAKER et al. 1971). The volcanics of the Nyambeni Range situated northeast of Mt. Kenya, consist mainly of basaltic rocks. Their age ranges from Pliocene to Pleistocene (MASON 1955, Rrx 1967, BROTzU et al. 1984). A comparable succession of mainly Pleistocene basaltic lavas and pyroclastics occurs at the Kilimanjaro volcano. Pleistocene and Holocene basaltic lavas and pyroclastics are found in the Chyulu Range.

\section{Key transects}

The spatial relationship between the geology and morphology of the study area is illustrated in four East-West oriented key transects (fig. 2, 3, 4, 5). The most northern section the Meru transect (section A-A', fig. 1) extends from the Tana Lamu basin through the Nyambeni range to the rift valley. The Chuka section more to the south (section B-B', fig. 1) crosses from the Tana-Lamu basin over the southern footslopes of Mt. Kenya, the Aberdare Range to the rift valley. Further south the Kitui section (section C-C', fig. 1) crosses mainly basement terrain. The most southern section of Kajiado (section D-D', fig. 1) displays a relief increase near the Yatta plateau and the rift shoulder.

All these east-west sections show a similar succession of younger (flat plains, Pf) and older (sloping, plains, Ps) plains, with stripped terrain above or below their surface. In the west the plains are bounded by volcanic plateaus of basement areas on

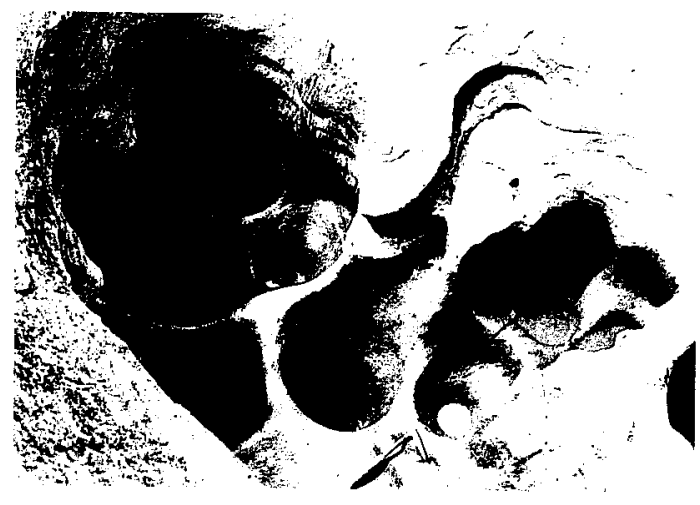

Photo 3. Excavated pothole from the transition zone shown in photo 2 . 
ly being dissected by both permanent and intermittent rivers, especially towards the southern part of the coast. The transition towards the older plains is marked by zone with numerous waterholes and locally minor cliffs in structural ridges or inselbergs. Exposed rock platforms on both Precambrian basement and Permo-Triassic sandstones in the waterhole zone are occupied by potholes of 0.1 to over $4 \mathrm{~m}$ wide (photo 2). Excavation of several potholes in the southwestern part of the study are (photo 3) showed that they contain gravel with an eastern (downstream) provenance (OOSTEROM 1988). The zonal distribution, the sediment content and the similarity with the potholes in the actual marine abrasion platform indicate that they were most likely formed in a former surf-zone (Oostrerom 1988).

Sedimentary evidence for a Late Pliocene transgression of a shallow sea on the End-Tertiary surface in the Lamu embayment has been given by SAGgERson \& BAKER (1965). Comparable sediments on flat topped interfluves in the southeast of the study area (OOSTEROM 1988) show that this coastal submergence affected southeast Kenya as a whole. SAGgerson \& BAKER (1965) concluded that this transgression was caused by coastal downwarp during the third phase of rifting in central Kenya. From radiometric dating of the rift volcanics it is now known that this tectonic activity lasted from 2.0 to $1.7 \mathrm{my} \mathrm{BP}$ (BAKER et al. 1978). At least seven episodes of high sea-level (marine climatic stages $81,79,77,75,73,71$ and 67 ) are known to have occurred during this episode (HARLAND 1990). This combination of alternating sea levels and coastal downwarp most probably led to the formation of the younger plains with both erosional and sedimentary characteristics.

\section{Older plains}

The older plains have an overall seaward gradient of about $0.5 \%$ and occur parallel to the younger plains west of the waterhole zone. The none-dissected parts of these older plains are characterized by deeply weathered soils (SOMBROEK 1982). Along major rivers such as the Tana, Athi and Tiva, the plain surface has been deeply dissected, resulting in a strongly lithologically controlled relief (PYE et al. 1986) Above the older plains lithologically controlled terrains are also found. These high areas consist of inselberg complexes or inverted lava-flows. The older plains can be seen widening from the northern Meru cross-section to the southern Kajiado crosssection.

In the Meru area (section A-A', fig. 1) a relative narrow zone of undissected older plains is found. The older plains are partly covered by the Nyambeni volcanics. Major scarps in both basement rocks and the oldest Nyambeni volcanics mark the western boundary of the older plains. A comparable scarp morphology can be seen in the Chuka section (cross section B-B'). The older plains are separated from the volcanic scarp by a wide zone of deeply dissected terrain, where etching and stripping is the dominant denudation process (VELDKAMP \& VISSER 1992). Its topographic position below the level of most western extension of the plain surface sug gests that the relief in transition zone must have developed from the older plains This is further evidenced by the dissected terrain in the Kitui section (section C-C') where flat topped interfluves are still found on the Kangondi-Tulia Plateau (OJary 1978). In the most southern Kajiado section (section D-D'), the non dissected older plains are again bounded by a scarp. The volcanic Yatta plateau stands clearly above the level of the sloping plain, while the Pleistocene volcanoes of the Chyulu Range clearly have been piled upon the plain surface.

Evidence for a sedimentary cover comparable to that of the younger plain is relatively scarce due to deep tropical weathering. However, infilled valleys with lagoonal-like sediments including lignite have been reported from the Kitui and Amboseli-Kibwezi areas (SANDERS 1954, Touber 1979). Strongly calcareous montmorillonitic clays, abruptly overlying Precambrian basement rocks, occur on the flat-topped interfluves of the Kangondi-Tulia Plateau (ScotT 1963, Sombromk 1982). Deep weathering with groundwater laterites are found at the foot of the plainbounding scarps in the Chuka area (DE MEESTER \& LEGGER 1988). These deeply weathered residual deposits point to prolonged stationary conditions and show that scarp retreat and related leveling of the older plains in SE Kenya were episodic processes like those forming the younger plains. From these similarities in morphology and evidence of the leveling processes, it is assumed that the origin of the older plains is comparable to the younger plains. This would imply that, during the active formation of the older plains, the area must also have been near base level and within the reach of coastal processes. A proper time setting of the active episode and evidence for contemparaneously base-level changes are essential to sustain this conclusion.

Time setting

The plain-formation process and related major scarp retreat on both the younger and older plains seem to be inactive under the present conditions. Thick and deeply weathered regoliths with locally groundwater laterites (SOMBROEK 1982, DE MEESTER \& LEGGER 1988) indicate prolonged stationary conditions for the boundary scarps of the plains. This observations indicates that plain formation in SE Kenya is not a continuous process as suggested in the concept of cyclic and global pediplanation, but an episodic one. The younger plains were formed between 2.0 and $1.7 \mathrm{my}$ BP (BAKER et al. 1978). The maximum age range for the formation of the older plains is set by the ages of the inverted, older Yatta phonolites (13.2 my BP) and the coastward situated younger plains (2.0-1.7 my BP). This wide time range can be narrowed by the ages of a phonolite tephrite flow at $4.5+0.25 \mathrm{my} \mathrm{BP}$ and a basanite flow at $2.9+0.4 \mathrm{BP}$ (Botzu et al. 1984). Both lavas belong to the Nyamben volcanics and occur along the western most extension of the older plains. The phonolite tephrites flows, which are confined to former valleys (RIx 1967), pass without morphological change into the plains of the surrounding basement area. Outliers of the phonolite flows also lack any morphological discontinuity with the basement plains. This indicates that the phonolite flows were leveled by the same processes which formed the older plains in which they occur. In contrast, the overlying basanite flows protrude above the basement rocks and the phonolite rephrites with clear flow edges. Moreover, they appear to have fixed the morphological scarp in both volcanics and basement rocks at the eastern side of the Nyambeni Range (fig. 2). This shows that the active episode of levelling of the older plains and scarp formation near the Nyambenis took place between 4.5 and 2.9 my BP. A similar time setting can be reconstructed from evidence along the eastern foot slopes of $\mathrm{Mt}$. Kenya in the Chuka area, where three major volcanic events can be distinguished 
(VELDKAMP \& VISSER 1986). The first involved deposition of phonolite lavas in preexisting valleys, far below the level of the End-Tertiary surface. The phonolites belong to the oldest Mt. Kenya volcanics which, in the west, are known to overly the Sagana Falls basalts $\left(5.5 \pm 1.0 \mathrm{my} \mathrm{BP}{ }^{1}\right.$ ) of the Aberdare volcanics (BAKER 1967). This shows that during the Early Pliocene the Chuka area had a strongly dissected topography. In contrast, the succeeding lahars, which mark the second major volcanic event, did not follow valleys, but covered the whole landscape. They form wide and flat plateaus east of Mt. Kenya, presently bounded by scarps more than $100 \mathrm{~m}$ high. Younger lahars occur on top and in front of the scarps and in the incised river valleys more to the east. They are related to the third volcanic episode during which the main body of Mt. Kenya was built up (VELDKAMP \& VISSER 1986). Phonolites high on Mt. Kenya, marking the end of this third volcanic episode, have been dated at $3.1 \mathrm{my} B \mathrm{BP}^{2}$. Scarp formation and its fixation must therefore have taken place between c. 5.5 and $3.1 \mathrm{my} B P$.

In conclusion it can be said that at the most land inward situated parts of the sloping plains leveling and scarp formation took place in relative short time span between about 4.5 and 3.1 to $2.9 \mathrm{my} \mathrm{BP}$.

\section{Base-level changes}

Differences in slope gradients of the lavas and lahars at the eastern slopes of Mt Kenya (fig.6) indicate that regional base-level, actually the Tana river, fluctuated considerably during the Pliocene.

The inverted phonolite of the Ugaleri plateau in the Chuka area has a gradient of more than $1.5 \%$. The gradient of overlying plateau lahars is less steep (c. $0.6 \%$ ) and shows that the regional base-level had risen since the deposition of the underlying phonolites. The younger lahars, which fixed the erosion scarps in the plateau lahars, have again steeper gradients, indicating a lowering in regional base-level.

The comparable gradients and apparent continuity of the lahar plateaus and the older plains surface (fig. 3) show that during that active episode of levelling the regional base-level was relatively high. The rise in regional base-level was at leas $250 \mathrm{~m}$ as measured at the eastern end of the Ugaleri phonolite flow. A rise of this magnitude cannot be explained by changes in sediment fluxes or blockage of the Tana river as there is no continuous topographic barrier at the extrapolated level of the plateau lahars. This implies that these regional base-level changes are more likely to have been connected with relative changes in general base-level due to tectonic vertical movements.

Evidence for major relative sea-level changes are also provided by discontinuities in the coastal sedimentary succession (THOMPSON 1956, CANNON et al. 1981 a, Oosтerom 1988). The Early to Middle Miocene Baratumu formation shows to have been deeply dissected before it was overlain by the deposits of the Early Pliocene Marafa formation. Lateritic soil formation in the Marafa sediments and subsequent dissection took place before they were covered by deposits of the Late Pliocene Magarini formation (OOSTEROM 1988).

\footnotetext{
I W/220 F.M. Consultans for Geol. Surv. Kenya (unpublished). Cit. BaKer et al. 1971

2 KA 475 in EvERDEN \& CuRTts 1965.
}

It is likely that the older active episode of levelling took place under conditions of high regional base-level which seems to have been directly linked to relative high sea levels.

\section{Tectonic setting}

The present maximum elevation of the older plains ranges from 650 to $1400 \mathrm{~m}$ (fig. 2 to 5). Consequently, the levelled areas must have been considerably uplifted since their formation near sea-level. Mean uplift rates of about $0.1 \mathrm{~m} / \mathrm{ky}$ during the Pleistocene are known from the coastal terraces of SE Kenya (OOSTEROM 1988). Comparable epirogenetic uplift rates are known from the Pliocene coastal sediments of S. Africa (KING 1972). The absence of major tectonic disturbances of the $300 \mathrm{~km}$ long Yatta Plateau (Oosterom 1988) shows that if uplift took place, it affected southeast Kenya as a whole. Accepting an epirogenetic uplift rate of $0.1 \mathrm{~m} / \mathrm{ky} \mathrm{a} \mathrm{minimum}$ correction of c. $300 \mathrm{~m}$ for the elevation of older parts of the End-Tertiary surface is allowed.

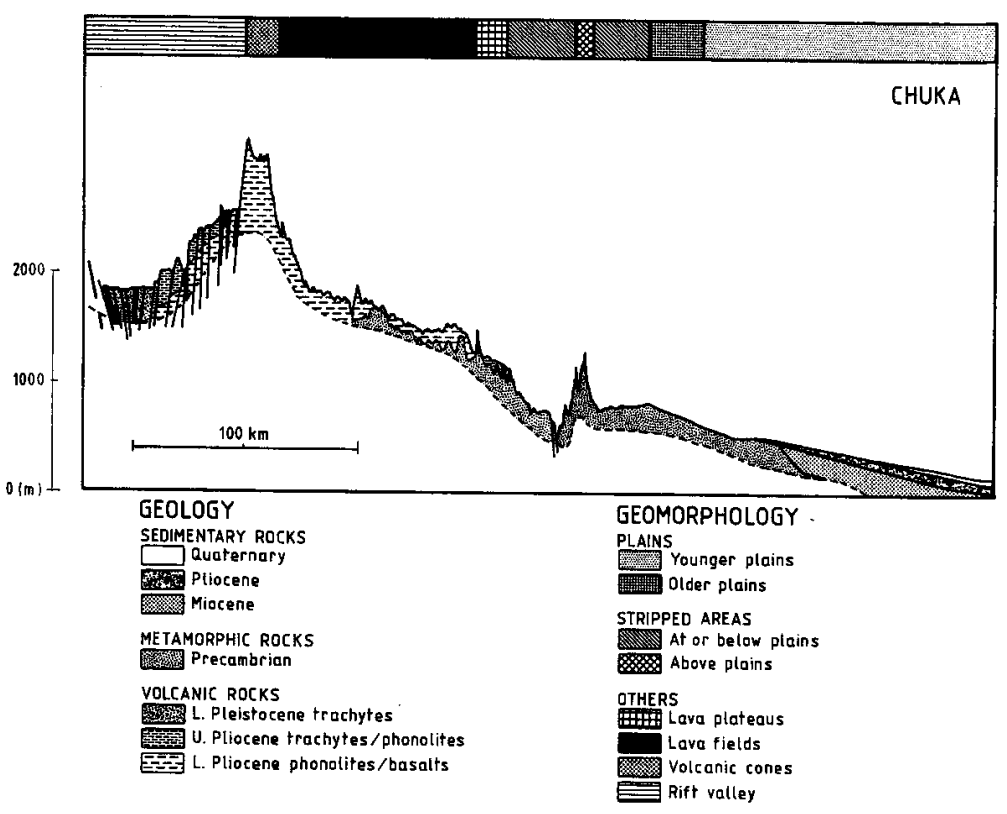

Fig. 3. Chuka transect. (section $B-B^{\prime}$ in fig. 1) 


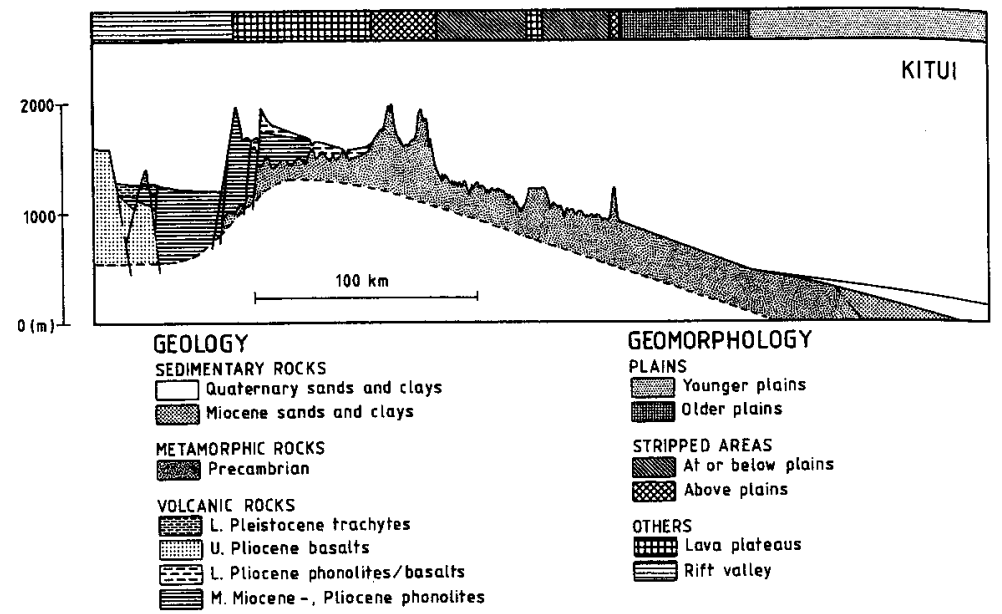

Fig. 4. Kitui transect. (section $C-C^{\prime}$ in fig. 1)

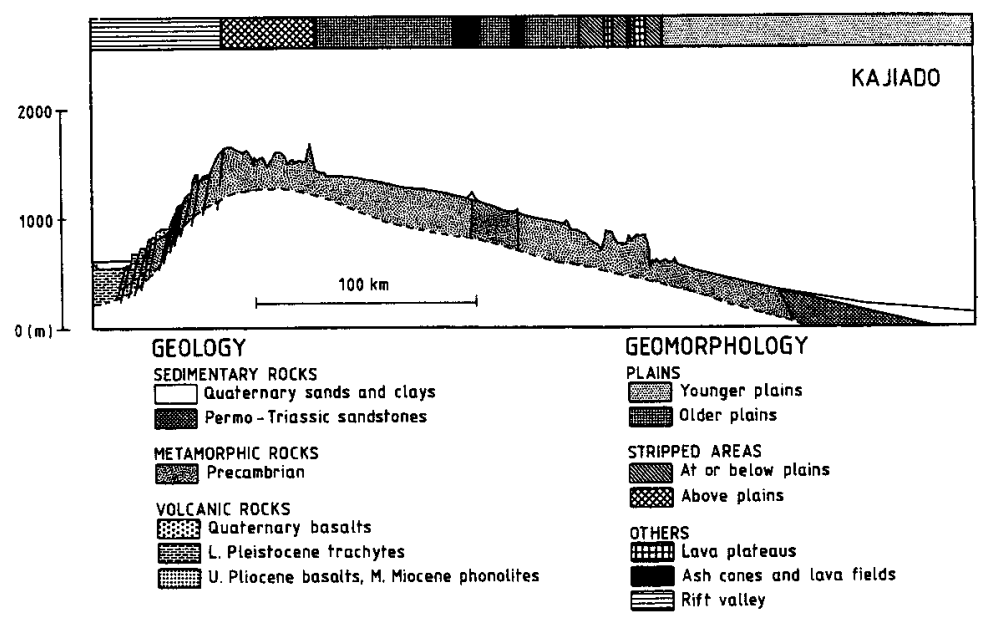

Fig. 5. Kjiado transect. (section D-D' in fig. 1)

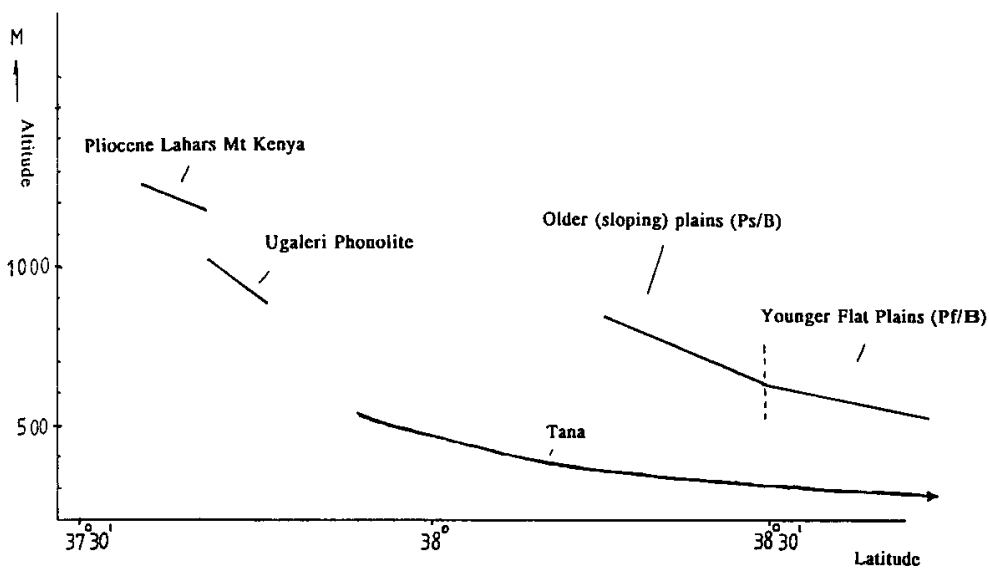

Fig. 6. Longitudinal profiles of phonolite flow (Ugaleri) and lahar plateau in Chuka area.

Besides epirogenetic uplift Kenya has known major tectonic events associated with the Eastern Rift-valley formation. Vertical displacements, associated with rif $t$ ing of more than $2000 \mathrm{~m}$ are known from the Middle Miocene volcanics in Central Kenya (MCCALL 1967). This available vertical displacement is more than sufficient to explain the present elevations of the older and younger plains (so-called End-Tertiary surface).

From the tectonic history of the rift valley west of the present study area, it is known that during the interval of 5-3 my BP active rifting took place (BAKER et al 1978). After the development of the Turoka-Ngong fault (500 m displacement), at about 3 my BP, tectonic activity along the rift died down. It lasted until 2-1.7 my B P before renewed activity occurred.

The present altitudes of the plains can be explained by tectonic uplift. Moreover, the coincidence of the time setting of the tectonic and base-level changes suggests a causal relationship.

\section{Discussion}

It has been demonstrated that plain formation in SE Kenya was episodic and most probably was related to a relatively high base-level which seems to have been tectonically controlled. Under the assumption that tectonic movements did indeed control the base-level changes the following sequence of events of the landscape development of SE Kenya can be reconstructed:

- prolonged etching and stripping dominating during the Miocene;

- tectonic activity in Central Kenya and contemporaneous gradual coastal subsi- 
dence, initiating plain formation near base-level during the Early Pliocene (c. 5-3 my $\mathrm{BP})$

- rift-faulting in Central Kenya, terminating plain formation by relative quick uplift at the beginning of the Late Pliocene (c. 3 my BP);

renewed etching and stripping and deep weathering on the emerged plains during the Late Pliocene;

- tectonic uplift in Central Kenya and contemporaneous gradual coastal subsidence, initiating near base-level plain formation during the Early Pleistocene (c. 2-1.7 my BP);

- rift-faulting in Central Kenya, terminating plain formation by relative quick uplift at c. $1.7 \mathrm{my}$ BP;

- renewed etching and stripping processes and soil formation on the emerged plains with terrace formation along major rivers and along the coast during the Pleistocene and Holocene.

During these events etching and stripping was acting uninterruptedly in the areas protruding above base-level. This implies that plain formation and etching and stripping were both contemporaneous and alternating processes in the landform development of SE Kenya. Herewith the conceptual paradox between the two is solved.

The study of the landform development of SE Kenya leads to the conclusion that the pediplain formation concept needs considerable revision. We propose an episodic levelling process initiated by a raise in base level, drowning the lower parts of the existing landscape. Erosion and sedimentation processes act along the edges of the drowned areas, filling in valleys and lowering interfluves. The great expanse of the plain can be explained by the many changes in base-level during the plain formation. Dissection and stripping continues in the areas above the reach of the rising base-level. The plain formation episode is most probably terminated by a major relative drop in base-level, associated with a marine regression. Etching and stripping start again to act on the emerged plains leading to renewed relief increase.

The proposed concept implies an important role of contemporaneous erosion and sedimentation near base-level. Taking into account the magnitude and geographical posittion of the plains in SE Kenya, two environments with similar active processes are interesting for further studies: shores of major lakes (e.g. Lake Victoria) and continental shelfs with both sedimentary and erosive parts. Especially the latter example is intriguing. The absence of a well developed continental shelf along the coast of SE Kenya and the presence of extensive plains in SE Kenya may then be explained by the same process: levelling near base level controlled by continental rifting. Of course more elaborate research is needed to test this speculative hypothesis. Only when the erosion and sedimentation events and the tectonic movements of Kenya are better reconstructed and dated, a more detailed interpretation of the plain formation events can be made.

\section{Acknowledgements}

Prof. S. B. Kroonenberg is thanked for his support and useful discussions. Ir P. W. VISSER is thanked for his assistence and support during the fieldwork in Kitui and Meru A. Weitz, Ir. W. Krabbe and P. Versteeg are thanked for their assistence with the manuscript and figure preparation.

\section{References}

BAKER, B. H. (1967): Geology of the Mount Kenya Area. - Report No. 79, Geol. Survey of Kenya, Nairobi, 78 pp., 1 map.

BAEER, B. H. T A., WTLIAMS, J. A. MTLLER \& F. J. Fitch (1971): Sequence and geochronology of the Kenya Rift volcanics. - Tectonophysics, 11: 191-215.

BAKER, B. H., R. CROSSLEY \& G. G. Goles (1978): Tectonic and magmatic evolution of the southern part of the Kenya Rift Valley. - In: E. R. Neuman \& I. B. Ramberg (eds.), Petrology and Geochemistry of Continental Rifts: 29-50. Reydel Publishing Company, Dordrecht, Holland.

Brotzu, P., L. Morbidelli, M. Nicoletti, E. M. Piccirillo \& G. Traversa (1984); Miocene to Quaternary volcanism in eastern Kenya: sequence and geochronology. - Tectonophysics, 101:

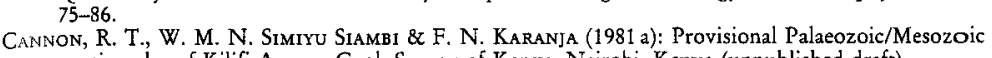
stratigraphy of Kilifi Area. - Geol. Survey of Kenya, Nairobi, Kenya (unpublished draft).

- - (1981): The proto-Indian Ocean and a probable Paleozoic/Mesozoic triadial rift system in East Africa. - Earth and Planetary Science Letters, 52: 419-426.

CHOUBerT, G. \& A. Faure-Muet (1976): Africa, explanatory note to sheet 6, 7, and 8. - In: Unesco \& Commission for the Geological Map of the World. Geological World Atlas, Unesco. Paris, France. Everden, J. F. \& G. H. CurTis (1965): The potassium-argon dating of Late Cenozoic rocks in East Africa

and Italy. - Current Antropology, 6: 343-385.
FaIRBURN, W. A. (1963): Geology of the North Machakos-Thika Area. - Report no. 59, Geol. Survey of

(1966): Geology of the Fort Hall Area. - Report no. 73, Geol. Survey of Kenya, Government Printer, Nairobi, 32 pp., 1 map.

Goudie, A., K. PYE \& A. WATSON (1984): The island hills of Kora. - The Geograph. mag. Sept.: 478-481. HarLand, W. B., R. L. ARmstrong, A. V. Cox, L. E. Craig, A. G. Smith \& D. G. SMItr (1990): A geological time scale 1989, - 263 pp., Cambridge Universiry Press, Cambridge.

Tiedermayr, R. E. A. OKello, W. Pohl \& J. K. Wachira (1979): Geology of the Taita Hills. - Geol. Survey of Kenya/Austromineral G.m.b.H., Inst. Geol. Univ. Wien, Osterreich.

Karanja, F. M. (1983): The Carboniferous to Tertiary continental sediments of East Kenya. - Ministry of Karanja, F. M. 15 pp.

KING, L. C. (1962): The morphology of the Earth. A study and synthesis of world scenery. - Oliver and Boyd, Edinburgh.

- (1972): The coastal plain of Southeast Africa: its form, deposits and development. - Z. Geomorph. N.F. 16: 239-251.

- (1976): Planation remnants upon high lands. - Z. Geomorph. N.F. 20: 133-148

Mason, P. (1955): Geology of the Meru - Isiolo area. - Report no. 31. Geol. survey of Kenya, Govern-

ment Printer, Nairobi, 26 pp., 1 map.
MCCALL, G. J. H. (1967): Geology of the Nakuru - Thompson's Falls - Lake Hennington Area. - Report

no. 78, Geol. Survey of Kenya, Government Printer, Nairobi, 122 pp., 2 maps.
MEESTER, T. DE \& D. LEGGER (1988): Soils of the Chuka-South area. - Agrc. Univ. Wageningen. Rep.

Dept. Soil Sci. Geol., 3 maps.
OJANY, F. F. (1966): The physique of Kenya. A contribution in landscape analysis. - Annals Assoc. American Geographers, vol. 56: 183-196.

- (1969): The inselbergs of Eastern Kenya with special reference to the Ukambani area. - Z. Geo-

morph. N.F. 13: 196-206.

(1978): Erosion and planation surfaces in the Machakos-Kitui area of Kenya. - Geojournal 2.4:

289-294; 2.5: 463-481.
OJANY, F. F. \& R. B. OGENDO (1973): Kenya: A Study in Physical and Human Geography. - 228 pp., Longman, Nairobi.

Oosterom, A. P. (1988): The geomorphology of Southeast Kenya. - Doctoral Thesis, Agricultural University, Wageningen. 227 pp., 1 map.

- (1989): Marine terraces in Southeast Kenya. A study of landscape development in the context of major Plio-Pleistocene climatic and tectonic events in East Africa. - Abstracts of posters and papers,

W. 8. G. NiEg Geomorphology, Frankfurt, p. 209 deposits of the area. - Geol. Survey of Kenya/Austromineral G.m.b.H., Inst. Geol. Univ. Wien, Osterreich. 
PYE, K., A. S. Goudie \& A. WATSON (1984): An introduction to the physical geography of the Kora Area, Central Kenya. - Geograph. J. 151: 168-181.

- - (1986): Petrological influence on differential weathering and inselberg development in the Kora area of Central Kenya. - Earth surface proc. and landforms, 11: 41-52. Rix, P. (1967): Geology of the Kinna Area. - Report no. 81, Geol. Survey of Kenya, Government Printer,
Nairobi, 36 pp., 1 map.

SAggerson, E. P. \& B. H. BaKer (1965): Post-Jurassic erosion-surfaces in eastern Kenya and their deformation in relation to rift structure. - Quart. J. geol. Soc. Lond. 121: 51-72.

SANDERS, L. D. (1954): Geology of the Kitui Area. - Report no. 30, Geol. Survey of Kenya, Government Printer, Nairobi, 37 Pp., 1 map.

- (1963): Geology of the Voi - South Yatta Area. - Report no. 54, Geol. Survey of Kenya, Government Printer, Nairobi, 48 pp., 2 maps.

Scort, R. M. (1963): Soils of Nairobi - Thika - Yatta - Machakos areas. - In: BeLlis, E. (1963): The soils of the Nairobi-Thika-Yatta-Machakos area. - Directorate of Overseas Surveys. Government Printer, Nairobi, $60 \mathrm{pp}$. Shackleton, R. M. (1945): Geology of the Nyeri Area. - Report no. 12, Geol. Survey of Kenya,
Government Printer, Nairobi,

Sombrozk, W. G., H. M. H. BRAun \& B. J. A. VAN Der Pouw (1982): Exploratory Soil map and Agroclimatic Zone map of Kenya. - Expl. soil Survey Report no. E1. Kenya Soil Survey, Nairobi,
Kenya. 56 pp., 4 maps. THOMAs, M. F. (1974): Tropical Geomorphology, a study of weathering and landform development in
warm climates. - London.

- (1980): Timescales of landform development on tropical shields. - A study from Sierra Leone. - In: Culuingford, R. A., D. A. Davidson, J. Levin \& M. F. Thomas 1980 (eds.), Timescales in Geomorphology.

- (1989): The role of etch processes in landform development, I. Etching concepts and their applications. - Z. Geomorph. N.F. 33: 129-142.

Thompson, A. O. (1956): Geology of the Malindi Area. - Report no. 36, Geol. Survey of Kenya, Government Printer, Nairobi. 63 pP., 1 map.

TOUBER, L. (1979): Soils and vegetation of the Amboseli-Kibwezi area. - Reconnaissance soil survey report no. R6 (Draft). Kenya Soil Survey, Nairobi, 88 pp., 2 maps.

VeLdKAMP, A. \& P. W. VISSER (1986): The geology of the Chuka-South area, Kenya. - Internal report, Department of soil science and geology, Wageningen, The Netherlands. - (1992): Erosion surfaces in the Chuka-South Area, Central Kenya. - Z. Geomorph. N.F., Suppl. 84:
147-158.

Walters, R. \& R. E. LinTon (1973): The sedimentary basin of coastal Kenya. - In: G. Blant (ed.), Sedimentary basins of African Coasts, part 1, South and East Coast. Ass. of Afr. Geol. Surv. Paris,
133-158.

WiLliams, L. A. J. (1978): The volcanological development of the Kenya Rift. In: E. R. Neuman \& I. R. RAMBERg 1978 (eds.), Petrology and geochemistry of continental rifts; 101-121, Ridel Publishing
Company, Holland.

Addresses of the authors: A.Veldokamp, Agricultural University, Wageningen, Department of Soil Science and Geology, P.O. Box 37, 6700 AA Wageningen, The Netherlands. - A.P. OOSTEROM, National Soil Service Project, P.O. Box 5088 Tanga, Tanzania. 